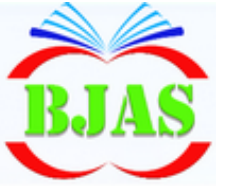

Available online at http://bjas.bajas.edu.iq

https://doi.org/10.37077/25200860.2020.33.2.17

College of Agriculture, University of Basrah

ISSN $1814-5868$

Basrah J. Agric. Sci., 33(2): 196-206, 2020
Basrah Journal

of Agricultural

Sciences

E-ISSN: 2520-0860

\title{
Effect of Adding Wings to the Shallow Tines on the Performance of Subsoiler Plow in the Soil Disturbed Area, Soil Pulverization Index \& Equivalent Energy of Pulverization
}

\author{
Murtadha A. A. Alfaris*, Salim Almaliki \& Sadiq J. Muhsin \\ Department of Agriculture Machines and Equipment, College of Agriculture, University of \\ Basrah, Iraq \\ *Corresponding author-mail: murtadha130@gmail.com \\ Received 24 May 2020; Accepted 25 September 2020; Available online 6 November 2020
}

\begin{abstract}
The experiment was performed using locally manufactured subsoiler plow provided with wings on the outside of shallow tines feet to study the impact of adding the wings and depth of tillage on the disturbance area of soil, soil pulverization index (mean weight diameter, MWD) and the equivalent energy of soil pulverization (Eq EP) in clay soil. This experiment was done in Randomized Complete Block Design (RCBD), with three replications having a factorial experiment. Three tillage depths $(40,50$, and $60 \mathrm{~cm})$ with and without wings on the feet of shallow tines were used. The results showed that the impact of adding wings and tillage depths had a significant effect on the disturbance area, soil pulverization index and the equivalent energy of soil pulverization $(\mathrm{p}<0.05)$. The treatment of adding wings on shallow tines $(\mathrm{S}+\mathrm{shw})$ has pre-eminence in studied factors. The disturbed area increased by $11.11,14.29$ and 9.80\%, the MWD decreased by 27.33, 32.31 and $19.38 \%$ and the Eq EP increased by $43.19,53.03$ and $25.13 \%$ when the depth of tillage increased from 40,50 and $60 \mathrm{~cm}$ respectively.
\end{abstract}

Keywords: subsoiler plow, wings, disturbed area, means weight diameter, equivalent energy.

\section{Introduction}

The tillage considered one of the main steps to create the seed cradle. Therefore the plowing tools take out the energy into the soil to produce desired effects such as cutting, breaking, inversion, and movement of soil. Soil is thus, transformed from the solid initial condition to the desired final condition by this process, (Ros et al., 1995). Frequent conventional tillage on the same depths during soil preparation, it leads to increase soil compaction. Also, soil compaction increases during processes of the break up the soil which that require passage the tractor in the field for more than once in the heavy soils as well as increase crush soil to micro granules. Basrah located in the southern Iraq, where the soil structure is heavy and the processes may be lead to soil degradation which affects both of the growth vegetative and yield of the crops as a result of the compact layers, increasing in bulk density and penetration resistance, thereby that lead to reduce water movement in the soil (Lal, 1997; 
Melesse et al., 2009; Jabro et al., 2010; Aday et al., 2011a). Therefore, there are alternative methods of the tillage and soil management should be used to reduce the traversing of the tractor in the field (Gill, 1969; Botta et al., 2006; Kadhim \& Subr, 2012). Using the subsoiler plow is an especial common technique used to tear down hardpans; therefore it required a high draft force (Godwin et al., 1981; Raper \& Sharma, 2002; Desale et al., 2012). Some modifications have been made, such as adding wings and shallow tines to improve the performance and profits from the available power (Kasisira \& du Plassis, 2006).

The disturbed soil can be defined as the crumble, move, and mixing that leads to a decrease in bulk density and change in the location of the loosening soil for three directions, particularly in the vertical direction of soil. These changes were caused by a tool passing through the soil. Consequently, the tool must be designed optimally to the soil disturbance parameters composition which includes: push back the critical depth, rake angle, shallow tines, and adding wings. Moreover, adding wings lead to change the soil failure to crescent shape for three dimensional (forward, lateral and vertical) soil movements (Godwin \& Spoor, 1977; Aday et al., 2011b; Barr et al., 2018). Also, affected the form of the furrow, soil throw on the side and blended the layers vertically by adding the wings (Sharifat, 1999; Desbiolles \& Saunders, 2006; Solhjou et al., 2012; Hasimu \& Chen, 2014).

Dogra et al. (2014) showed that the mean weight diameter of the clods size increased with an increase in blade width. Mean weight diameter varied between 2.22 to $12.15 \mathrm{~mm}$ at different width blade. Minimum weight diameter (MWD) was observed for $10 \mathrm{~cm}$ wide blade and $4.62 \mathrm{~Hz}$ spading frequency. Maximum weight diameter (MWD) was observed for blade $15 \mathrm{~cm}$ wide and $1.85 \mathrm{~Hz}$ spading frequency. The soil was crumbled when used the forwarding bent-winged tine plow more than the backward one plow. The reason for that the conventional winged tine is the removal of soil from down to the surface, but the bent-winged tool cut the soil in the subsurface and moved it vertically during it moved forward; therefore, the soil has teardown into small pieces. (Askari et al., 2019).

One of the most approaches to reduce the requirements of energy can be achieved by increasing the efficiency of tillage. The required energy to operate a tillage tool in the soil is used to overcome the mechanical strength of the soil and to cause displacement, which results in break-up the soil (Muhsin, 2017; Almaliki, 2018; Almaliki et al., 2019). According to what indicated it Tisdall \& Oades (1982), macro aggregates was larger than $200 \mu \mathrm{m}$, so it was more affected compared to the micro aggregate $(2-200 \mu \mathrm{m})$. The action of the direct plowing tools and equipment probably does not result in the important dismantling of soil. Therefore the macro aggregate and the agglomerate soil have partly shredded by the plowing tools (Balesdent et al., 2000). Soil pulverization requires more energy for breaking the soil to small pieces which decrease the soil mean weight diameter and increases the pulverization (Khadr, 2008).

A few researchers studied the effect of wings in the subsoiler on soil fragmentation and disassemble, which reflect on knowledge of farmers about using the tine's wings and their benefit in soil tilling. Most of previous studies confirm that adding wings with subsoiler and tines was significant in the 
performance of the subsoiler. However, the studies about effects of wings on soil fragmentation were specific and rare. The published researches of such literature show that the used wings can be included the rake angle and the attack angle which consider very important in the efficiency of the subsoiler performance. However, there is no comprehensive study of this respect. The objective of this study is to reach the cognition of the impact of adding wings to shallow tines in the subsoiler plow in the soil mean weight diameter and equivalent energy for pulverization. The main goal of the research is to determine the mean weight diameter of the plowing soil area, which was scrutinized in terms of the suitability of the loosened area for direct seed implants.

\section{Materials \& Methods}

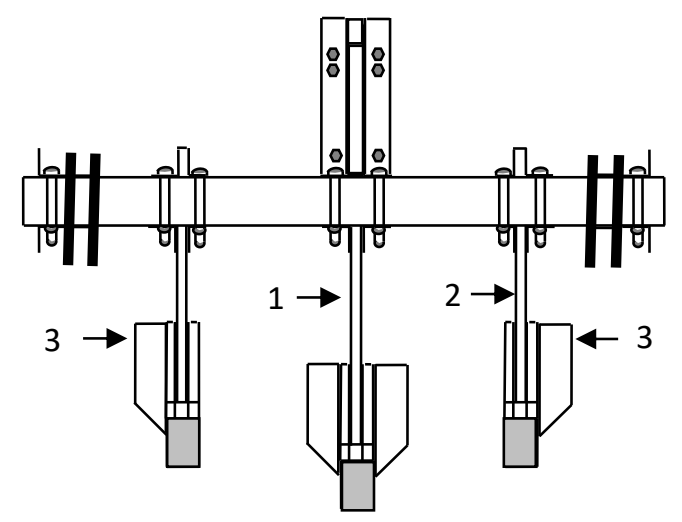

(A)

\section{Characteristics of subsoiler plow}

The subsoiler plow was designed and manufactured in the Department of Agricultural Machines and Equipment, College of Agriculture, University of Basrah (Fig. 1). It consists of the frame attached to the leg forward angle (rake angle) of $60^{\circ}$. The foot was fixed at the end of the subsoiler leg. The penetration angle of the front of the foot is $35^{\circ}$. The foot was provided two wings fixed on both sides at the inclination angle of $25^{\circ}$. The width of the foot together with the wings is $30 \mathrm{~cm}$. The subsoiler plow was provided with two shallow tines at a distance of $36 \mathrm{~cm}$ forward of the subsoiler plow. The lateral distance (distance between shallow tines) can be changed. Each foot of shallow tines provided with wing fixed on the outside. The width of the foot together with a wing is $20 \mathrm{~cm}$.

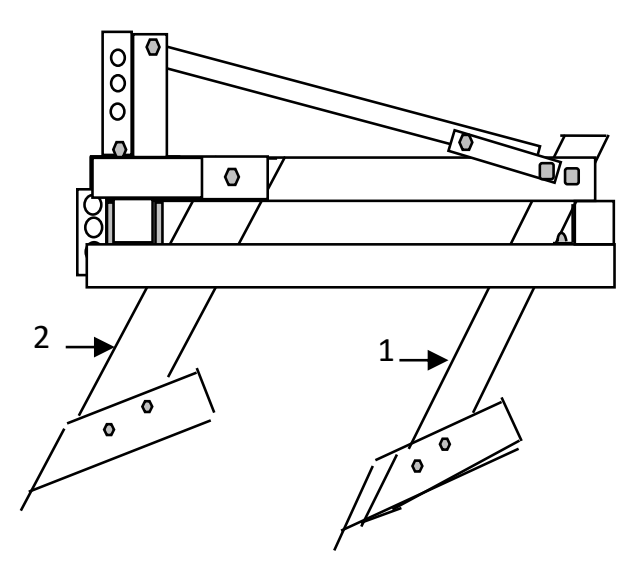

(B)

Fig. (1): The schematic subsoiler (A) Front view, (B) Side view

\section{$1=$ subsoiler plow, $2=$ shallow tines, $3=$ wings}

\section{Soil properties}

The field experiments were carried out in Research Station farm of Agriculture College of university Basrah in soil clay texture; their limits of consistency were shown in table (1). The soil samples were taken before experiment execution to estimate the moisture content and bulk density (Black et al., 1965). The penetration resistance, cohesion, and adhesion strength were measured from 10 to $60 \mathrm{~cm}$ (Gill \& Vanden Berg, 1968). The results of soil analysis were presented in table (2). 
Table (1): Soil texture and consistency limits

\begin{tabular}{ccccc}
\hline $\begin{array}{c}\text { Sand } \\
\mathrm{g} \mathrm{Kg}^{-1}\end{array}$ & $\begin{array}{c}\text { Silt } \\
\mathrm{g} \mathrm{Kg}^{-1}\end{array}$ & $\begin{array}{c}\text { Clay } \\
\mathrm{g} \mathrm{kg}^{-1}\end{array}$ & $\begin{array}{c}\text { Liquid limit } \\
\%\end{array}$ & $\begin{array}{c}\text { plastic limit } \\
\%\end{array}$ \\
\hline 70.60 & 325.40 & 604.00 & 48.66 & 26.83 \\
\hline
\end{tabular}

Table (2): The physical and mechanical properties of experiment soil.

\begin{tabular}{ccccc}
\hline $\begin{array}{c}\text { Depth } \\
\mathrm{cm}\end{array}$ & $\begin{array}{c}\text { Moisture } \\
\text { content } \%\end{array}$ & $\begin{array}{c}\text { Bulk density } \\
\mathrm{Mg} . \mathrm{m}^{-3}\end{array}$ & $\begin{array}{c}\text { Cone index kN. } \\
\mathrm{m}^{-2}\end{array}$ & $\begin{array}{c}\text { Cohesion } \\
\mathrm{kN} . \mathrm{m}^{-2}\end{array}$ \\
\hline $0-10$ & $14.40 \pm 0.66$ & $1.20 \pm 0.03$ & $1266.56 \pm 9.27$ & $13.30 \pm 0.60$ \\
\hline $10-20$ & $20.70 \pm 0.75$ & $1.23 \pm 0.10$ & $1241.24 \pm 6.46$ & $14.89 \pm 0.44$ \\
\hline $20-30$ & $21.07 \pm 0.96$ & $1.15 \pm 0.08$ & $1241.24 \pm 3.98$ & $16.54 \pm 0.41$ \\
\hline $30-40$ & $21.98 \pm 0.57$ & $1.36 \pm 0.04$ & $1551.55 \pm 5.88$ & $19.22 \pm 0.57$ \\
\hline $40-50$ & $22.53 \pm 0.61$ & $1.40 \pm 0.05$ & $1681.68 \pm 5.10$ & $21.34 \pm 0.88$ \\
\hline $50-60$ & $25.29 \pm 0.64$ & $1.30 \pm 0.09$ & $1480.00 \pm 7.00$ & $18.79 \pm 0.47$ \\
\hline
\end{tabular}

\section{Data collection}

The tillage was carried out on long lines of 15 $\mathrm{m}$ by using Massy-Ferguson tractor, (2680, 4WD). The rated power of the tractor is 96.98 $\mathrm{kW}$, at a forward speed of $0.34 \mathrm{~m} \mathrm{sec}^{-1}$. After the tillage process, the soil was left to dry in the field. The disturbed soil was removed by hand for a length of $50 \mathrm{~cm}$ and to width of soil disturbed for each line at all tillage depths beyond the trench and the undisturbed soil profile exposed was measured by measuring the dimensions of the trench, then convert it to a geometric shape (Fig. 2), and calculating the area by the equation (1).

$\mathrm{A}=\frac{(\mathrm{L} 1+\mathrm{L} 2)}{2} * \mathrm{~d}$

$\mathrm{A}=$ disturbed area, $\mathrm{L} 1=$ soil surface disturbed, $\mathrm{L} 2=$ the bottom of ditch, $\mathrm{d}=$ depth of tillage.

The soil out of the trench was collected for all tillage depths. Then it was passed through a series of different sizes of sieves with diameters (120, 90, 50, 30, 10 and $2 \mathrm{~mm}$ ). The clods of the diameter greater than 120 $\mathrm{mm}$ were measured by using the measuring tape. The mean weight diameter (MWD) was calculated by using equation (2).

$$
X i=\sum_{i=1}^{n} \frac{W i * M}{W}
$$

Where $X i$ : is the mean weight diameter $(\mathrm{mm}), W i$ : is the mass of soil on each sieve $(\mathrm{kg}), M:$ is the average sieve size $(\mathrm{mm}), W$ : is the mass of soil sample $(\mathrm{kg})$.

Different soil samples were randomly collected from each tillage depth at moisture content about $4.90 \%$. After that, the samples were separately weighted, for three replicates. The pulverization energy was calculated from a break up the soil clods by a crash drop from a height $0.80 \mathrm{~m}$ according to Gill \& McCreery (1960) using the following formula (3).

$$
Q=M * g * Z * n
$$

Where:

$Q:$ is the pulverization energy $(\mathrm{kJ}), M$ : is the mass of sample $(\mathrm{kg}), g$ : is the acceleration $(\mathrm{m} \mathrm{sec}-2), Z$ : is the vertical distance of fall 

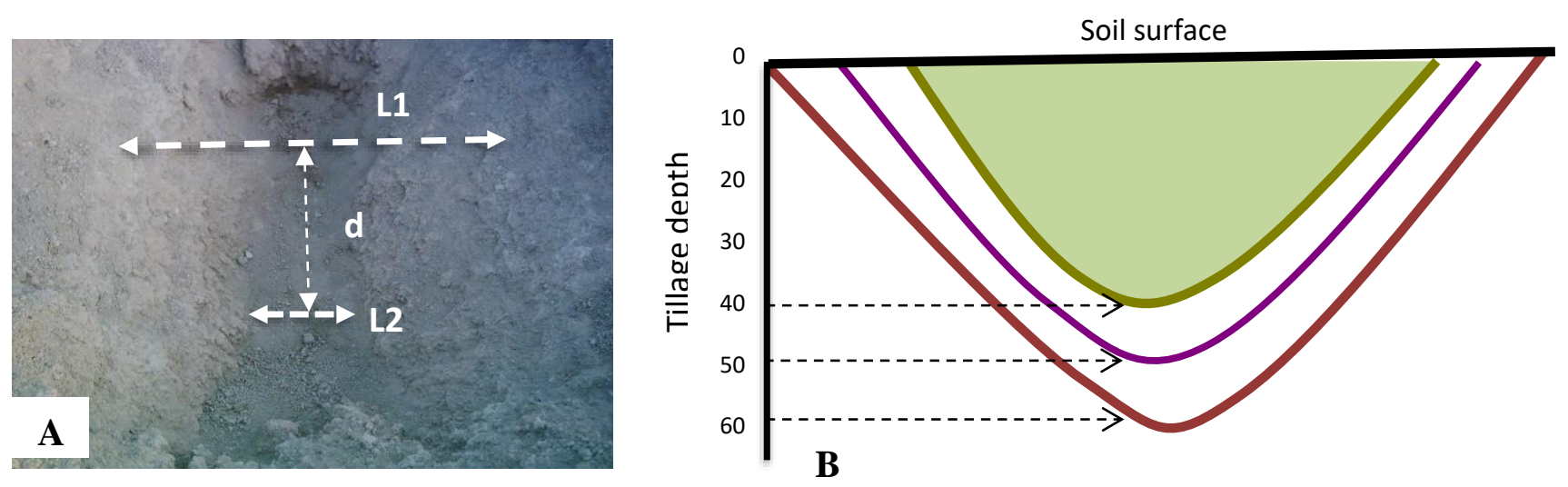

Fig. (2): A- Actual shape, B- Soil geometric shape as a consequence of the subsoiler plow action.

down $(0.80 \mathrm{~m})$, and $n$ : is the times number of the fall down.

The MWD for the obtained small pieces of the soil after a number of dropping were calculated by using the same sieves who using in calculation the MWD in the field. The relationship between the MWD and the pulverization energy was determined by using a logarithmic scale of the axis X (fig. 3). The pulverization energy of the disturbed soil by the subsoiler plow was calculated per each plowing depth by using equation (4) consequent from the graph to determine the amount of energy used for the pulverization.

$$
\cdot y=-23.17 * \operatorname{Ln}(x)+112
$$

Where $\mathrm{y}$ : is the mean weight diameter ( $\mathrm{mm})$, $\mathrm{x}$ : is the energy required for the pulverization $\left(\mathrm{kJ} . \mathrm{Mg}^{-1}\right)$.

The equivalent energy for pulverizing $(\mathrm{kJ}$. $\mathrm{Mg}^{-3}$ ) was calculated by multiplying the pulverization energy required and soil bulk density at different depths. The experience was performed using a complete randomized block design (RCBD) with three replications and the data were analysed using Genstat. The differences between averages were compared using LSD at a level of 0.05 (Table 4).

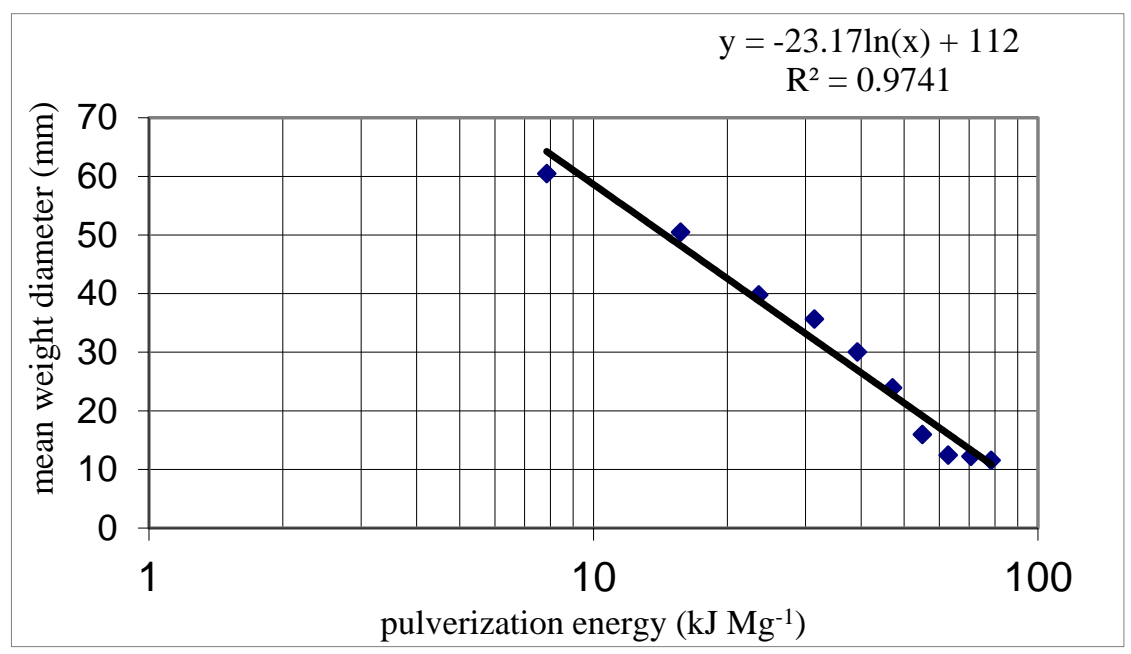

Fig. (3): Correlation between energy required and mean weight diameter. 


\section{Results \& Discussion}

\section{The disturbed area of soil}

The results in the table (3) showed that the effect of wings and tillage depth in the disturbance area was significant differences at $(\mathrm{P}<0.05)$. Increasing of the disturbed area (27.59 and 23.24\%) when the depth increment from 40 to 50 and then $60 \mathrm{~cm}$ sequentially while the increment was $10.53 \%$ when adding the wings.

With increasing tillage depth and adding wings, the disturbance soil was increased, the results displayed in table (3). This goes back to during movement of the plow in the soil, it is cut off the soil and send it to the sides of the plow. The edge of the furrow of the disturbance soil generated was observed beyond the plowing line of the trench similar to an isosceles triangle. This result was compatible with that reported by Liu \&
Kushwaha (2006). Adding the wings on the feet of the shallow tines was substantial effect on the soil disturbance parameters as they all incremented when the plowing depth increment. This could be returned to control parameters nature of soil failure or disturbance is the (depth/width ratio). Moreover, the rake angle leads to increase the forward rupture distance and lateral cracks. Then it's led to the crescent failure formation of the soil (Godwin \& Spoor, 1977; McKyes, 1985).

The interaction between the depth of tillage and adding the wings on the feet of shallow tines in the disturbance area was significant effect $(p<0.05)$. The disturbance area increased by $11.11,14.29$ and $9.80 \%$ for the adding wings treatment $(\mathrm{S}+\mathrm{shw})$ compared with without wings treatment $(S+s h)$ when increase tillage depth from 40 to 50 and $60 \mathrm{~cm}$ respectively (Table 3 ).

Table (3): Effect depths of tillage and adding wings to shallow tines in disturbed area $\left(\mathrm{m}^{2}\right)$

\begin{tabular}{lcccc}
\hline \multicolumn{5}{c}{ Depth of tillage (cm) (D) } \\
\hline S+sh & 40 & 50 & 60 & Mean \\
\hline S+shw & $0.27^{\mathrm{a}} \pm 0.03$ & $0.35^{\mathrm{c}} \pm 0.04$ & $0.51^{\mathrm{e}} \pm 0.01$ & $0.38^{\mathrm{a}}$ \\
\hline Mean & $0.29^{a}$ & $0.40^{\mathrm{d}} \pm 0.02$ & $0.56^{\mathrm{f}} \pm 0.03$ & $0.42^{\mathrm{b}}$ \\
\hline
\end{tabular}

$\mathrm{S}+\mathrm{sh}=$ Subsoiler + shallow tines, $\mathrm{S}+\mathrm{shw}=$ Subsoiler + shallow tines + wings, $\mathrm{D}=$ depth of tillage. Values are means $\pm \mathrm{SE}$ Obtained from three replications. The means with the different letters had significant effect at a probability level of 0.05.

It noticed the percentage of the increase in the soil disturbance increased when increasing the depth from 40 to 50 and then decreased at the depth $60 \mathrm{~cm}$. this is because of the shallow tines with wings are working at the front of the subsoiler plow and at different soil in the properties such as moisture content, bulk density and penetration resistance at the depth at $50 \mathrm{~cm}$ (Table 2). This caused an increase in a crescent failure zone and reduced the pressure of soil on the foot of the subsoiler plow. Then, it's led to an increase in the lateral cracks of soil by the subsoiler plow. 
Table (4): Statistical analysis of the test (F) of the values of area, MWD, and the Eq EP.

\begin{tabular}{ccccc}
\hline Source & df & Area & MWD & Eq EP \\
\hline D & 2 & $2086.95^{*}$ & $5141.21^{* *}$ & $403.53^{*}$ \\
\hline W & 1 & $215.12^{*}$ & $24609.13^{* *}$ & $2787.36^{*}$ \\
\hline D x w & 2 & $9.88^{*}$ & $684.74^{* *}$ & $60.83^{*}$ \\
\hline
\end{tabular}

$\mathrm{D}=$ depth of tillage, $\mathrm{W}=$ wings, $*$ significant differences at level $0.05, * *$ at level 0.01

\section{Mean weight diameter (Pulverization index)}

As shown in the table (5), the results showed significant effect at $(\mathrm{P}<0.05)$ of the tillage depth in the Mean weight diameter (MWD). The MWD decreased $3.70 \%$ and $15.45 \%$ when the depth increased 40 to $60 \mathrm{~cm}$ respectively. The reason of this increases maybe due to the increase in the volume of the soil loosing with increase of the tillage depth, which leads to increase the collisions between the soil clods. The MWD decreased in a greater rate when the depth increased from 50 to $60 \mathrm{~cm}$ compare with increase the depth from 40 to $50 \mathrm{~cm}$. This is because the depth of the shallow tines relative to the depth of the subsoiler, where they are working in depth of soil which is different in the bulk density and moisture content in both depths (Table 2).

When adding the wings to the shallow tines, they significantly effected in the MWD. The MWD decreased $26.54 \%$ in comparison to without adding wings as shown in the table (5).
This may be due to the adding of the wings to the shallow tines led to increase the contact area with soil, as well as increasing the volume of soil loosing and thus increase the movement of the clods and collision soil clods with each to other (Aday et al., 2011a).

In the context of interaction between the depth of plow and adding the wings was significantly affected $(p<0.05)$ in the MWD. The treatment of adding wings overcome shallow tines $(\mathrm{S}+\mathrm{shw})$ in decreased the MWD by $27.33,32.31$ and $19.38 \%$ when increase the depth of tillage from 40,50 and $60 \mathrm{~cm}$ respectively. The depth of tillage $50 \mathrm{~cm}$ gave the high rate in the decrease of the MWD comparative with other depths. This is because the shallow tines work at depth of soil that bulk density is $1.15 \mathrm{Mg} . \mathrm{m}^{-3}$ and moisture content $20.07 \%$ which is nearly from friable status. Also, adding the wings on the feet lead to increase contact area with soil and then increase the acceleration of clods, causing increase the fragmentation.

Table (5): Effect depths of tillage and adding wings to shallow tines in MWD (mm)

\begin{tabular}{lcccc}
\hline \multicolumn{5}{c}{ Depth of tillage (cm) (D) } \\
\hline S+sh & $\mathbf{4 0}$ & $\mathbf{5 0}$ & $\mathbf{6 0}$ & Mean \\
\hline S+shw & $38.62^{\mathrm{a}} \pm 0.98$ & $37.88^{\mathrm{b}} \pm 0.85$ & $31.35^{\mathrm{c}} \pm 0.71$ & $35.95^{\mathrm{a}}$ \\
\hline Mean & $34.43^{\mathrm{d}} \pm 0.99$ & $28.63^{\mathrm{e}} \pm 0.68$ & $26.26^{\mathrm{f}} \pm 0.79$ & $28.41^{\mathrm{b}}$ \\
\hline
\end{tabular}

$\mathrm{S}+\mathrm{sh}=$ Subsoiler + shallow tines, $\mathrm{S}+\mathrm{shw}=$ Subsoiler + shallow tines + wings, $\mathrm{D}=$ depth of tillage. Values are means $\pm \mathrm{SE}$ Obtained from three replications. The means with the different letters had significant effect at a probability level of 0.05 . 


\section{Equivalent energy}

The depth of plow had a significant effect on the equivalent energy for the pulverization (Eq EP). An increasing in Eq EP (7.84\% and $11.60 \%)$ when the depth of tillage increased from 40 to $60 \mathrm{~cm}$ respectively (Table 6). These increases may be returned to an increase in the depth of tillage that leads to an increase in the cracks of the soil. Moreover, the moisture content of the soil also close to the friable status thus increased the volume of the soil loosening when the depth of plow increased, which reduced the energy required to penetrate and cut the soil, that's made the subsoiler plow exploits of the energy available in fragmentation of the soil. This result is agreement with Panwar \& Siemens (1972) and Aday et al. (2001).

Adding of the wings to the feet of shallow tines led to a significant increasing $(p<0.05)$ in the Eq EP. It's increased by $39.20 \%$ because to increase the area of contact between the soil and wings, that's led to utilize of the energy available in the soil fragmentation as shown in table (6). The interaction between the depth of tillage and the wings in the Eq Ep significantly increased $(\mathrm{p}<0.01)$ when increasing the depth and adding the wings. Its increased by 43.19 , 53.03 and $25.13 \%$ for $(S+$ shw $)$ compared with $(\mathrm{S}+\mathrm{sh})$ when increase the tillage depth from 40 to 50 and $60 \mathrm{~cm}$, respectively. The maximum and minimum percentages of increase in the Eq EP was at the depth tillage 50 and $60 \mathrm{~cm}$ respectively. The reason of this maybe to the depth of the shallow tines and depth of the subsoiler plow were worked at different soil in the properties of the soil such as moisture content, bulk density and penetration resistance at the depth of $50 \mathrm{~cm}$ (Table 2). As well as the volume of the soil loosening lead to exploiting part of the energy available in fragmentation soil.

Table (6): Effect depths of tillage and adding wings in $\operatorname{Eq~} \operatorname{EP}\left(\mathrm{kJ} \mathrm{m}^{-3}\right)$.

\begin{tabular}{|c|c|c|c|c|}
\hline \multicolumn{5}{|c|}{ Depth of tillage (cm) (D) } \\
\hline & 40 & 50 & 60 & Mean \\
\hline S+sh & $32.21^{\mathrm{a}} \pm 0.89$ & $33.38^{\mathrm{b}} \pm 1.00$ & $41.87^{\mathrm{c}} \pm 1.02$ & $35.82^{-\mathrm{a}}$ \\
\hline S+shw & $46.12^{\mathrm{d}} \pm 0.99$ & $51.08^{\mathrm{e}} \pm 0.98$ & $52.39^{f} \pm 1.07$ & $49.86^{\mathrm{b}}$ \\
\hline Mean & $39.16^{a}$ & $42.23^{b}$ & $47.13^{c}$ & \\
\hline
\end{tabular}

\section{Conclusions}

This experiment showed that adding the wings to the shallow tines as well as increase depth of subsoiler plow lead to an increase in soil disturbance area, improve the soil pulverization (reduce mean weight diameter). Moreover, led to improving the performance of the subsoiler plow in using the equivalent energy for pulverization in clay soil under conditions of implementation of the experiment. The increase percentage of the studied properties is affected by increase in the depth of subsoiler plow and the change in soil characteristics, such as soil moisture and bulk density. 


\section{Acknowledgments}

This paper was supported by the Department of Agricultural Machines and Equipment, College of Agriculture, University of Basrah, Iraq.

\section{Orcid:}

Murtadha A. A. Alfaris

https://orcid.org/0000-0002-9515-5624

Salim Almaliki

https://orcid.org/0000-0002-9115-7518

Sadiq J. Muhsin

https://orcid.org/0000-0001-9512-9947

\section{References}

Aday, S. H., Abdulnabi, M. A., \& Ndawi, D. R. (2011a). The effect of the lateral distance of the shallow tines on the disturbed area and the specific resistance of the subsoiler. Basrah Journal of Agricultural Sciences, 24, 23-41. https://cutt.ly/gfaIVN6

Aday, S H., Al-dosary, S. H., \& Hassan G. C. (2011b). The effect of the tractor passes on the soil bulk density in silty clay soil. Basrah Journal of Agricultural Sciences, 24, 11- 27.

https://cutt.ly/mfaI1Mb

Aday, S. H., Hameed, K. A., \& Salman R. F. (2001). The energy requirement and energy utilization efficiency of two plows type for pulverization of heavy soil. Iraqi Journal of Agricultural Sciences, 6 , $136-146$.

https://cutt.ly/JfaI93Z

Almaliki, S. (2018). Simulation of draft force for three types of plow using response surface method under various field conditions. Iraqi Journal Agriculture Science, 49, 1123-1131.

https://doi.org/10.36103/ijas.v49i6.151

Almaliki, S., Himoud, M., \& Muhsin, S. J. (2019). A stepwise regression algorithm for prognostication draft requirements of disk plough. Journal of Engineering \& Applied Sciences, 14, 10335-10340. http://dx.doi.org/10.36478/jeasci.2019.10335.10340

Askari, M, Shahgholi, G., \& Abbaspour-Gilandeh, Y., (2019). New wings on the interaction between conventional subsoiler and paraplow tines with the soil: effects on the draft and the properties of soil, Archives of agronomy and Soil Science, 65, 88100. https://doi.org/10.1080/03650340.2018.1486030

Balesdenta, J., Chenub, C., \& Balabane, M. (2000). Relationship of soil organic matter dynamics to physical protection and tillage. Journal Soil and Tillage Research, 53, 215-230. https://doi.org/10.1016/S0167-1987(99)00107-5

Barr, J B., Ucgul, M., Desbiolles, J., M.A., Fielke J., M. (2018). Simulating the effect of rake angle on narrow opener performance with the discrete element method. Bioystems Engineering, 171, 1-15. https://doi.org/10.1016/j.biosystemseng.2018.04.013

Black, C. A., Evans, D. D., Whit, J. L., Ensminger L. E., \& Clark, F. E. (1965). Methods of Soil Analysis. Part 1, No. 9. American Society of Agronomy. Madison, Wisconsin, 770pp.

https://cutt.ly/TfMbzhj

Botta, G. F., Jorajuria, D. R., Balbuena, Ressia M., Ferrero, C., Rosatto, H., \& Tourn, M., (2006). Deep tillage and traffic effects on subsoil compaction and sunflower (Helianthus annus L.) yields. Soil \& Tillage Research, 91, 164-172. https://doi.org/10.1016/j.still.2005.12.011

Desale, A., K., Melesse, T., L., \& Abdu Abdelkadir, M., (2012). Effect of winged subsoiler and traditional tillage integrated with Fanya Juu on selected soil physico-chemical and soil water properties in the Northwestern highlands of Ethiopia. East African Journal of Sciences, 6, 105116. https://cutt.ly/QfaOeD5

Desbiolles, J. M. A., \& Saunders, C. (2006). Soil throw characteristics of no-till furrow openers: A pilot study. In Paper presented at the 17th triennial conference of the international soil and tillage research organization, Kiel, Germany. https://cutt.ly/UfaOqDc

Dogra R., Ahuja, S., S., Dogra, B. \& Virk, M., S., (2014). Effect of Blade Width and Spading Frequency of Spading Machine on Specific Soil Resistance and Pulverisation. Agricultural mechanization in asia, africa, and latin America, $45,12-17$ https://cutt.ly/ZfaOwdf 
Gill, W. R. (1969). Soil deformation by simple tools. Transactions of the ASAE, 12, 234-239. doi: 10.13031/2013.38807

Gill, W. R., \& McCreery, W. F. (1960). Relation of size cut tillage tool efficiency. Agriculture Engineering, 41, 372-381.https://cutt.ly/2faOphN

Gill, W. R., \& Vanden Berg, G. E. (1968). Soil Dynamics in Tillage and Traction, Handbook316, Agricultural Research Service, US Department of Agriculture, Washington D. C, 511pp. https://cutt.ly/nfaOuje

Godwin, R. J., \& Spoor, G. (1977). Soil failure with narrow tines. Journal of Agricultural Engineering Research, 22, 213228.https://doi.org/10.1016/0021-8634(77)90044-0

Godwin R. J., Spoor, G., \& Leeds-Harrison, P. (1981). An experimental investigation into the force mechanics and resulting soil disturbance of mole ploughs. Journal of Agricultural Engineering Research, 26, 477497.https://doi.org/10.1016/0021-8634(81)90081-0

Hasimu, A., \& Chen, Y. (2014). Soil disturbance and draft force of selected seed openers. Soil \& Tillage Research, 140 , 48e54.https://doi.org/10.1016/j.still.2014.02.011

Jabro, J. D., Stevens, W. B., Iversen, W. M., \& Evans, R. G. (2010). Tillage depth effects on soil physical properties, sugarbeet yield and sugarbeet quality. Communications in Soil Science \& Plant Analysis, 41 , 908-

916.https://doi.org/10.1080/00103621003594677

Kadhim, N. S., \& Subr, A., K. (2012). Effect of tillage with chisel plow on soil mean weight diameter and porosity. The Iraqi Journal of Agricultural Sciences, 43, 33-41. https://cutt.ly/YfaOdcN

Kasisira, L. L., \& du Plassis, H. L. M. (2006). Energy optimization for subsoilers in tandem in a sandy clay loam soil. Soil \& tillage Research, 68, 185198. https://doi.org/10.1016/j.still.2005.02.031

Khadr, Kh. A. A., (2008). Effect of some primary tillage implement on soil pulverization and specific energy Misr Journal Agriculture Engineering, 25, 731-745.https://cutt.ly/sfaOgPX

Lal, R. (1997). Long-term tillage and maize monoculture effects on a tropical Alfisol in Western Nigeria. Crop yield and soil physical properties. Soil \& Tillage Research 42, 145-160. https://doi.org/10.1016/S0167-1987(97)00006-8
Liu, J., \& Kushwaha, R.L., (2006). Modeling of soil profile produced by a single sweep tool. Agricultural Engineering International: the CIGR Ejournal, Manuscript PM 06 008, 8, https://cigrjournal.org/index.php/Ejounral/article/vi ew/652/646

Melesse, T., Hoogmoed, W. B., Savenije, H. H. G. \& Rockstrom, J., (2009). Conservation tillage implements and systems for smallholder farmers in semi-arid Ethiopia. Soil \& Tillage Research 104, 185-191. https://doi.org/10.1016/j.still.2008.10.026

McKyes, E., (1985). Soil Cutting and Tillage. Elsevier Science Publishing Company Inc., New York, NY10017, 226pp. https://cutt.ly/YfIc3W2

Muhsin, S. J. (2017). Determination of energy requirements, plowed soil volume rate and soil pulverization ratio of chisel plow under various operating conditions. Basrah Journal of Agricultural $\quad$ Sciences, 30, 7384.https://doi.org/10.37077/25200860.2017.24

Panwar, I. S., \& Siemens, J. (1972). Shear strength and energy of soil failure related to density and moisture. Transactions of the ASAE, 15, 423-427. https://cutt.ly/9fa18Rx

Raper, R. L., \& Sharma, A. K. (2002). Energy Requirement and soil disruption of subsoiling. Beltwide Cotton Conferences, Atlanta GAJanuary, 8-12. 3pp.https://cutt.ly/1fa0moY

Ros, V., Smith, R. J., Marley S. J., \& Erbach, D. C., (1995). Mathematical modeling and computer aided design of the passive tillage tools, Transactions of the ASAE, 38, 675-683. https://cutt.ly/3fa2ygS

Sharifat, K. (1999). Soil translocation with tillage tools. Ph. D. Thesis. College of Graduate Studies and Research, University of Saskatchewan, 159pp. https://cutt.ly/bfaOkvk

Solhjou, A., Fielke, J. M., \& Desbiolles, J. M. A. (2012). Soil translocation by narrow openers with various rake angles. Biosystems Engineering, 112, 65-73.

https://doi.org/10.1016/j.biosystemseng.2012.02.00 6

Tisdall, J. M., \& Oades, J. M. (1982). Organic matter and water stable aggregates. Journal Soil Science, 33, 141-163. https://doi.org/10.1111/j.13652389.1982.tb01755.x 
تأثير اضافة الاجنحة الى المحاريث الضحلة في اداء المحراث تحت سطح التربة في مساحة التربة المفكة، دليل التقتيث والطاقة المكافئة للتفتيت

مرتضى عبد العظيم الفارس وسالم عجر المالكي وصادق جبار محسن

قسم المكائن و الآلات الزر اعية، كلية الزر اعة، جامعة البصرة، العراق

الخلاصة: نفذت التجربة باستخدام محراث تحت سطح التربة مصنع محلياً مزود بأجنحة على أقدام المحاريث الضحلة من الجهة الخارجية بهدف دراسة تأثير إضافة الأجنحة وعمق الحراثة على مساحة التربة المفككة ودليل تفتيت التربة. (معدل القطر الموزون ، والطاقة المكافئة للتفتيت (MPD) في التربة الطينية، بتصميم القطاعات العشوائية الكاملة، لثلاثة مكررات بتطبيق تجربة عاملية. تم استخدام ثلاثة أعماق للحراثة 40 و 50 و 60 سم مع وبدون اضافة الأجنحة على أقدام المحاريث الضحلة

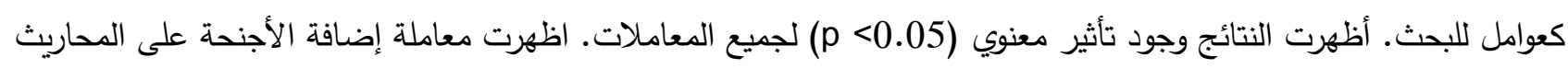

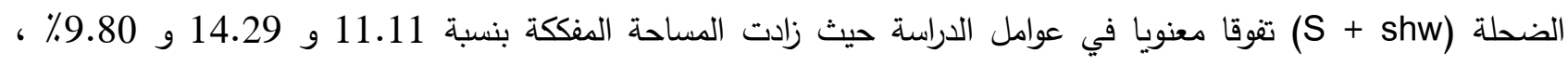

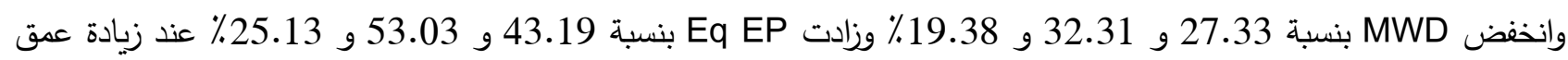
الحراثة من 40 و 50 و 60 سم على التوالي. كلمات مفتاحية: محراث تحت سطح التربة، الاجنحة، المساحة المفككة، معدل القطر الموزن، الطاقة المكافئة للتفتيت. 